\title{
Keefektifan fosfin formulasi cair terhadap Aphis gossypii Glover dan Macrosiphoniella sanborni Gillette (Hemiptera: Aphididae) pada bunga potong krisan
}

\author{
Effectiveness of liquified phosphine formulation against \\ Aphis gossypii Glover and Macrosiphoniella sanborni Gillette \\ (Hemiptera: Aphididae) on chrysanthemum cut flowers
}

\author{
Nur Rachman ${ }^{1,2}$, Dadang ${ }^{1}$, R. Yayi Munara Kusumah ${ }^{1}$ \\ ${ }^{1}$ Departemen Proteksi Tanaman, Fakultas Pertanian, Institut Pertanian Bogor \\ Jalan Kamper, Kampus IPB Dramaga, Bogor 16680 \\ ${ }^{2}$ Stasiun Karantina Pertanian Kelas II Bangkalan \\ Jalan Kusuma Bangsa No. 20, Kabupaten Bangkalan 69162
}

(diterima Maret 2015, disetujui September 2015)

\begin{abstract}
ABSTRAK
Bunga potong krisan merupakan tanaman hias yang banyak diminati oleh masyarakat karena memiliki nilai estetika dan ekonomi yang tinggi. Volume ekspor bunga krisan dari Indonesia masih relatif rendah dibandingkan dengan negara lain. Hal ini diakibatkan oleh beberapa kendala di antaranya adalah terdapatnya organisme pengganggu tumbuhan pada bunga yang diekspor. Dua dari beberapa hama pada bunga krisan adalah Aphis gossypii Glover dan Macrosiphoniella sanborni Gillette. Salah satu perlakuan karantina untuk membebaskan komoditas pertanian dari hama adalah fumigasi. Alternatif fumigan yang memiliki keefektifan yang baik adalah fosfin formulasi cair. Tujuan dari penelitian ini adalah untuk menentukan konsentrasi dan lama pemaparan yang dapat mematikan A. gossypii dan M. sanborni pada bunga potong krisan dan mengevaluasi kualitas bunga yang diperlakuan fumigan tersebut. Penelitian dilakukan sebanyak 4 tahapan, diantaranya (1) identifikasi dan perbanyakan A. gossypii dan M. sanborni; (2) uji pendahuluan terhadap fase nimfa instar III dan imago; (3) aplikasi konsentrasi dan waktu papar fosfin formulasi cair terhadap fase nimfa instar III dan imago dari A. gossypii dan M. sanborni; dan (4) uji validasi konsentrasi dan waktu papar fosfin formulasi cair yang efektif dan mengevaluasi pengaruh terhadap kualitas bunga potong krisan. Hasil penelitian menunjukkan konsentrasi fumigan menyebabkan kematian $100 \%$ terhadap A. gossypii dan M. sanborni berturut-turut adalah $500 \mathrm{ppm}$ dan $700 \mathrm{ppm}$, dengan lama pemaparan 12 jam. Penggunaan fosfin formulasi cair konsentrasi hingga $700 \mathrm{ppm}$ dan lama pemaparan hingga 18 jam tidak berdampak buruk pada kualitas bunga potong krisan.
\end{abstract}

Kata kunci: fumigan, fumigasi, kematian, konsentrasi, waktu pemaparan

\begin{abstract}
Cut flower of chrysanthemum has high aesthetic and economic values. Export volume of chrysanthemums from Indonesia are lower than other countries, due to the impact of insect pest. Insect pests, Aphis gossypii Glover and Macrosiphoniella sanborni Gillette are currently associated with cut flowers especially chrysanthemum. One control measures usually taken in quarantine is
\end{abstract}

\footnotetext{
*Penulis korespondensi: Nur Rachman. Stasiun Karantina Pertanian Kelas II Bangkalan, Jalan Kusuma Bangsa No. 20, 
fumigation. Alternative fumigant, liquified phosphine formulations may potentially be applied for quarantine treatment. The objectives of this study were to determine the concentration and exposure time of liquified phosphine against these species and to evaluate the effect of fumigant on the physical quality of cut flowers. The experiment was conducted in four steps: (1) identification and mass rearing of $A$. gossypii and $M$. sanborni; (2) preliminary tests on adult and third instar nymphs; (3) determination of liquified phosphine with various concentration and exposure time against adult and third instar nymphs of A. gosspypii and M. sanborni and; (4) validation test of effective concentration of fumigant and exposure time and the effect on quality of cut flowers. The results of study showed concentration of fumigant causing $100 \%$ mortality A. gossypii and M. sanborni were $500 \mathrm{ppm}$ and $700 \mathrm{ppm}$, respectively with exposure time 12 hours. Concentrations of $700 \mathrm{ppm}$ and exposure time up to 18 hours did not cause negative impact to the quality of chrysanthemum cut flowers.

Key words: concentration, exposure time, fumigan, fumigation, mortality

\section{PENDAHULUAN}

Indonesia dikenal sebagai negara yang memiliki kekayaan keanegaraman hayati termasuk flora. Berbagai jenis tanaman hias dapat tumbuh dengan baik. Empat jenis bunga yang dipasarkan baik pasar dalam negeri maupun pasar internasional ialah mawar (Rosa spp.), anggrek (Phalaenopsis spp.), krisan (Chrysanthemum spp.) dan sedap malam (Polianthes spp.). Bunga krisan merupakan salah satu tanaman hias yang banyak diminati oleh masyarakat karena memiliki nilai estetika dan ekonomi yang tinggi. Total volume ekspor bunga ini pada tahun 2012 mencapai 79,10 ton dengan nilai US\$1.647.127, dan mengalami penurunan pada tahun 2013 menjadi 57,05 ton dengan nilai sekitar US\$ 772.117 (BPS 2014). Nilai ini masih relatif lebih rendah dibandingkan dengan negara lain. Hal ini disebabkan oleh beberapa kendala diantaranya adalah terdapatnya organisme pengganggu tumbuhan (OPT) berupa serangga hama pada bunga yang diekspor.

Beberapa serangga dapat menyerang pertanaman bunga krisan dua diantaranya, ialah kutudaun Aphis gossypii Glover dan Macrosiphoniella sanborni Gillette, yang merupakan hama penting pada Chrysanthemum indicum (Dixon 1998; Rostami et al. 2012). Selain sebagai hama, serangga ini juga dapat berperan sebagai vektor virus. Berdasarkan international standards for phytosanitary measures (ISPM) No. 34: Design and operation of post-entry quarantine stations for plants bahwa hama yang dapat bersifat sebagai vektor harus dicegah penyebarannya (IPPC 2011). Mengingat hal tersebut maka negara pengekspor perlu memperhatikan kualitas dan kuantitas dari produk pertaniannya. Adanya infestasi serangga pada bunga menyebabkan negara pengimpor harus membebaskan infestasi serangga atau menolak bunga potong tersebut sehingga perlakuan karantina tanpa merusak bunga dibutuhkan sesuai persyaratan negara pengimpor.

Fumigasi sebagai perlakuan karantina tumbuhan bertujuan untuk membebaskan komoditas pertanian dari OPT. Target dalam tindakan perlakuan karantina harus dapat mematikan serangga hama secara sempurna (zero tolerant). Setidaknya terdapat tiga jenis fumigan yang digunakan secara luas, yaitu metil bromida, fosfin, dan sulfur flourida. Fosfin diketahui merupakan fumigan yang memiliki efek fitotoksisitas yang lebih rendah pada bunga potong dibandingkan dengan metil bromida, karbonil sulfida, dan hidrogen sianida (Weller \& Graver 1998). Selain itu, fosfin formulasi padat memiliki beberapa kelemahan, yaitu membutuhkan waktu papar lama dan berisiko terbakar apabila diaplikasikan pada komoditas dengan kadar air yang tinggi (Barantan 2013). Untuk itu, dibutuhkan formulasi alternatif dari fumigan fosfin yang memiliki keefektifan yang lebih baik dan tidak menimbulkan dampak negatif bagi komoditas yang difumigasi. Pengembangan fosfin dengan gas karbon dioksida dilakukan untuk meningkatkan toksisitas fumigan ini. Fosfin formulasi cair yang diperdagangkan pada tabung silinder bertekanan tinggi, dengan komposisi formulasi 2\% $\mathrm{PH}_{3}$ (fosfin) dan $98 \%$ $\mathrm{CO}_{2}$ merupakan bahan fumigan yang tidak mudah terbakar. Hingga saat ini belum diketahui konsentrasi dan lama pemaparan fumigan fosfin formulasi cair yang efektif untuk pengendalian A. gossypii dan M. sanborni pada bunga potong krisan dan pengaruhnya terhadap kualitas bunga potong krisan. Tujuan penelitian ini adalah untuk menentukan konsentrasi dan lama pemaparan fosfin formulasi cair yang dapat mematikan $A$. 
gosyypii dan M. sanborni pada bunga potong krisan dan untuk mengevaluasi kualitas bunga yang diperlakukan fumigan tersebut.

\section{BAHAN DAN METODE}

Penelitian dilaksanakan di Laboratorium Entomologi dan Gedung Workshop Fumigasi Balai Uji Terap Teknik dan Metode Karantina Pertanian, Bekasi yang berlangsung mulai bulan Agustus 2014 hingga Desember 2014.

\section{Penyiapan serangga uji}

Identifikasi kutudaun. Kutudaun yang didapatkan dari lapangan identifikasi untuk memastikan bahwa serangga yang akan diuji adalah $A$. gossypii dan $M$. sanborni. Indentifikasi dilakukan berdasarkan kunci identifikasi kutudaun Blackman \& Eastrop (2000; 2006). Identifikasi dilakukan dengan membuat preparat slide dari sampel serangga uji. Secara umum karakter kutudaun yang menjadi ciri identifikasi adalah bentuk antena tuberkel, kauda, dan kornikel.

Perbanyakan kutudaun. Kutudaun (A. gossypii dan M. sanborni) dikoleksi dari lapangan, kemudian dipelihara dan diperbanyak pada tanaman krisan. Menurut Tamaki \& Allen (1969), kedua spesies kutudaun tersebut memiliki kemampuan adaptasi yang baik pada tanaman krisan. Krisan ditanam pada pot yang ditutup kain organdi dan diletakkan di rumah kaca. Serangga uji yang digunakan adalah nimfa instar III dan imago yang berumur relatif sama. Pemilihan fase nimfa instar III dan imago dalam penelitian ini disebabkan oleh fase nimfa instar III merupakan fase yang paling tahan terhadap fumigan, dan fase imago merupakan fase yang paling rentan dibandingkan dengan fase lain. Menurut penelitian Park et al. (2010) bahwa fase nimfa kutudaun lebih tahan terhadap fosfin dibandingkan dengan fase imago. Selain itu, menurut Duan \& Zhang (2004) instar ketiga lebih tahan terhadap suhu ekstrem dibandingkan dengan nimfa instar kesatu dan keempat.

\section{Uji pendahuluan}

Pengujian pendahuluan dilakukan terhadap 30 individu nimfa instar III atau imago $A$. gossypii atau M. sanborni yang diinfestasikan pada bibit krisan. Kapas basah diberikan pada bagian perakaran untuk menjaga kesegaran tanaman selama perlakuan, kemudian diletakkan dalam kotak plastik $(8 \mathrm{~cm} \times 8 \mathrm{~cm} \times 11 \mathrm{~cm})$. Waktu pemaparan yang ditetapkan adalah 6,12 , dan 18 jam dengan 5 taraf konsentrasi fosfin formulasi cair $(0,50,100,200,300 \mathrm{ppm})$ yang diulang sebanyak 3 kali. Mortalitas serangga diamati 1 jam setelah perlakuan (JSP).

\section{Uji lanjut terhadap $A$. gossypii dan $M$. sanborni}

Uji lanjut dilakukan terhadap imago dan nimfa instar III $A$. gossypii dan M. sanborni pada kombinasi waktu papar dan konsentrasi terbaik dari hasil uji pendahuluan. Pada uji lanjut ini, perlakuan diujikan pada masing-masing 1 ikat bunga potong krisan tipe spray (terdiri atas 10 bunga potong) yang pada setiap ikat bunga diinfestasikan 30 individu imago atau nimfa instar III A. gossypii atau $M$. sanborni. Bunga potong diletakkan dalam kotak kertas $(60 \mathrm{~cm}$ x $20 \mathrm{~cm}$ x $20 \mathrm{~cm})$ yang ditutup dengan kain kasa. Uji lanjut dilakukan pada 3 waktu papar $(12,15$, dan 18 jam $)$ dengan 6 taraf konsentrasi fosfin formulasi cair $(0,300,400$, $500,600,700 \mathrm{ppm}$ ) yang diulang sebanyak 3 kali. Mortalitas serangga diamati 1 JSP.

\section{Uji validasi dan pengaruh fosfin cair pada bunga potong krisan}

Uji validasi dilakukan berdasarkan hasil uji lanjut yang memberikan persentase mortalitas $100 \%$. Uji validasi dan pengaruh terhadap kualitas bunga potong ini dilakukan pada 2 taraf konsentrasi (0 dan 700 ppm) dengan 3 waktu papar $(12,15$, dan 18 jam) yang diulang sebanyak 3 kali. Perlakuan diujikan terhadap 2 varietas bunga krisan, yaitu Zembla white dan Fiji white dengan masing-masing 1 ikat bunga potong krisan (terdiri atas 10 bunga potong). Setiap bunga potong diinfestasi dengan 30 individu imago atau nimfa instar III A. gossypii atau M. sanborni. Bunga potong diletakkan dalam kotak kertas $(60 \mathrm{~cm} \times 20 \mathrm{~cm} \times 20 \mathrm{~cm})$ yang ditutup dengan kain kasa. Setelah aplikasi fosfin formulasi cair, dilakukan penghitungan mortalitas A. gossypii dan M. sanborni serta evaluasi kualitas bunga potong krisan. Bunga potong yang telah difumigasi ditempatkan dalam ember berisi air. Pengamatan penurunan kualitas bunga khususnya 
layu dan bercak dilakukan pada 1, 24, 48, 72, 96, dan 120 JSP. Pengamatan dilakukan secara visual dengan teknik skoring. Skor kerusakan bunga diamati pada bagian yang layu dan bercak pada bunga berdasarkan Park et al. (2010), sebagai berikut:

0 : tidak terjadi kerusakan (bunga sehat);

1: kerusakan ringan $0 \%<\mathrm{x} \leq 5 \%$ (bunga layu sedikit);

2: kerusakan sedang, $5 \%<\mathrm{x} \leq 25 \%$ (bunga layu sebagian);

3: kerusakan berat, $\mathrm{x}>25 \%$ (bunga layu sebagian hingga mati).

\section{Analisis data}

Data dianalisis menggunakan Minitab 16 dan SAS 9.1. Model rancangan yang digunakan pada penelitian ini adalah rancangan acak lengkap faktorial. Ada tiga faktor perlakuan yang diuji, yaitu faktor A (fase serangga), faktor B (konsentrasi), faktor C (waktu pemaparan). Lethal concentration untuk tingkat mortalitas 50\% dan 95\% ditentukan menggunakan analisis probit.

\section{HASIL}

\section{Identifikasi kutudaun}

Hasil identifikasi kutudaun menunjukkan bahwa serangga uji adalah $A$. gossypii dan $M$. sanborni. Ciri morfologi $A$. gossypii adalah tubuh berbentuk oval dengan ukuran aptera $0,9-1,8 \mathrm{~mm}$ dan alatae 1,1-1,8 mm. A. gossypii memiliki antena tuberkel yang tidak berkembang, terminal process dari antena dua kali lebih panjang dari dasar segmen antena terakhir, kornikel cenderung berbentuk lancip dan berwarna gelap serta terdapat 4-7 helai rambut pada bagian kauda. Ciri morfologi $M$. sanborni adalah tubuh berbentuk lonjong dengan ukuran apterae 1,0-2,3 $\mathrm{mm}$ dan alatae 1,8-2,6 mm. M. sanborni memiliki antena tuberkel yang berkembang, kornikel dan kauda berwarna gelap, kornikel sedikit lebih kecil dibandingkan dengan kauda, antena segmen III, setengah proximal femur, dan bagian tengah tibia berwarna pucat.

\section{Aktivitas fosfin formulasi cair terhadap imago dan nimfa instar III $A$. gosypii serta M. sanborni}

Hasil uji lanjut aplikasi fosfin formulasi cair terhadap A. gossypii mendapatkan bahwa, mortalitas 100\% dicapai pada konsentrasi 400 ppm pada semua waktu papar untuk imago, sedangkan untuk nimfa instar III dicapai pada konsentrasi 500 ppm pada waktu papar 12 dan 15 jam, dan pada waktu papar 18 jam konsentrasi 400 ppm (Tabel 1). Hasil uji lanjut aplikasi fosfin formulasi cair terhadap M. sanborni, mortalitas $100 \%$ dicapai pada konsentrasi 600 ppm untuk imago, sedangkan untuk nimfa instar III dicapai pada konsentrasi 700 ppm pada waktu papar 12 dan 15 jam, dan konsentrasi 400 ppm pada waktu papar 18 jam (Tabel 2). Nilai penduga parameter toksisitas $\mathrm{LC}_{50}$ dan $\mathrm{LC}_{95}$ terendah

Tabel 1. Rata-rata persentase mortalitas imago dan nimfa instar III Aphis gossypii pada beberapa konsentrasi fosfin formulasi cair pada waktu papar 12, 15, dan 18 jam

\begin{tabular}{|c|c|c|c|c|}
\hline \multirow{2}{*}{ Fase serangga } & \multirow{2}{*}{ Konsentrasi (ppm) } & \multicolumn{3}{|c|}{ Rata-rata mortalitas $\pm \mathrm{SD}^{\mathrm{a}}(\%)^{\mathrm{b}}$} \\
\hline & & 12 jam & 15 jam & 18 jam \\
\hline \multirow[t]{6}{*}{$\overline{\text { Imago }}$} & 700 & $100,0 \pm 0,0 \mathrm{a}$ & $100,0 \pm 0,0 \mathrm{a}$ & $100,0 \pm 0,0 \mathrm{a}$ \\
\hline & 600 & $100,0 \pm 0,0 \mathrm{a}$ & $100,0 \pm 0,0 \mathrm{a}$ & $100,0 \pm 0,0 \mathrm{a}$ \\
\hline & 500 & $100,0 \pm 0,0 \mathrm{a}$ & $100,0 \pm 0,0 \mathrm{a}$ & $100,0 \pm 0,0 \mathrm{a}$ \\
\hline & 400 & $100,0 \pm 0,0 \mathrm{a}$ & $100,0 \pm 0,0 \mathrm{a}$ & $100,0 \pm 0,0 \mathrm{a}$ \\
\hline & 300 & $94,4 \pm 5,1 b$ & $97,8 \pm 1,9 \mathrm{ab}$ & $100,0 \pm 0.0 \mathrm{a}$ \\
\hline & 0 (Kontrol) & $0,0 \pm 0,0 \mathrm{e}$ & $0,0 \pm 0,0 \mathrm{e}$ & $0,0 \pm 0,0 \mathrm{e}$ \\
\hline \multirow{6}{*}{$\begin{array}{l}\text { Nimfa } \\
\text { instar III }\end{array}$} & 700 & $100,0 \pm 0,0 \mathrm{a}$ & $100,0 \pm 0,0 \mathrm{a}$ & $100,0 \pm 0,0 \mathrm{a}$ \\
\hline & 600 & $100,0 \pm 0,0 \mathrm{a}$ & $100,0 \pm 0,0 \mathrm{a}$ & $100,0 \pm 0,0 \mathrm{a}$ \\
\hline & 500 & $100,0 \pm 0,0 \mathrm{a}$ & $100,0 \pm 0,0 \mathrm{a}$ & $100,0 \pm 0,0 \mathrm{a}$ \\
\hline & 400 & $95,6 \pm 1,9 \mathrm{ab}$ & $97,8 \pm 1,9 \mathrm{ab}$ & $100,0 \pm 0,0 \mathrm{a}$ \\
\hline & 300 & $77,8 \pm 1,9 \mathrm{~d}$ & $83,3 \pm 3,3 \mathrm{c}$ & $95,6 \pm 5,1 \mathrm{ab}$ \\
\hline & 0 (Kontrol) & $0,0 \pm 0,0 \mathrm{e}$ & $0,0 \pm 0,0 \mathrm{e}$ & $0,0 \pm 0,0 \mathrm{e}$ \\
\hline
\end{tabular}

a: Standar deviasi; ${ }^{\text {b: }}$ Rata-rata persentase mortalitas yang diikuti oleh huruf yang sama menunjukan tidak berbeda nyata berdasarkan uji tukey taraf 5\%. 
ditunjukkan pada waktu papar 15 jam, yaitu berturut-turut $209,8 \mathrm{ppm}$ dan $397,8 \mathrm{ppm}$ untuk imago, serta 213,3 ppm dan 539,4 ppm untuk nimfa instar III (Tabel 3).

\section{Uji validasi dan pengaruh fosfin cair pada bunga potong krisan}

Uji validasi dan pengaruh pada bunga potong krisan dilakukan berdasarkan hasil uji lanjut dengan persentase mortalitas tertinggi (100\%). Uji validasi yang dilakukan pada 3 waktu papar (12, 15, dan 18 jam) pada konsentrasi 700 ppm menunjukkan persentase mortalitas $100 \%$ pada kedua fase kutudaun A. gossypii dan M. sanborni. Sementara pengaruh aplikasi fosfin formulasi cair terhadap bunga potong yang diamati hingga 120 JSP pada waktu papar 18 jam tidak menunjukkan hasil yang berbeda dibandingkan dengan kontrol baik untuk bunga potong krisan varietas Zembla white (Gambar 1) dan varietas Fiji white (Gambar 2). Rata-rata nilai skoring yang didapatkan pada setiap perlakuan adalah 0 yang diperlihatkan dengan tidak adanya layu maupun bercak pada bunga.

\section{PEMBAHASAN}

Waktu papar fumigan sangat berpengaruh terhadap kematian A. gossypii dan M. sanborni. Hal ini diperlihatkan pada lama pemaparan 6 dan 12 jam dengan konsentrasi 50-300 ppm yang tidak menyebabkan kematian (mortalitas) $100 \%$. Hal ini menunjukkan bahwa kedua spesies serangga ini tahan pada konsentrasi (50-300 ppm) dan lama pemaparan 6 dan 12 jam. Peningkatan lama pemaparan menjadi 18 jam dapat mematikan serangga uji hingga $100 \%$. Setiap spesies

Tabel 2. Rata-rata persentase mortalitas imago dan nimfa instar III Macrosiphoniella sanborni pada beberapa konsentrasi fosfin formulasi cair pada waktu papar 12, 15, dan 18 jam

\begin{tabular}{lcccc}
\hline \multirow{2}{*}{ Fase serangga } & \multirow{2}{*}{ Konsentrasi $(\mathrm{ppm})$} & \multicolumn{3}{c}{${\text { Rata-rata mortalitas } \pm \mathrm{SD}^{\mathrm{a}}(\%)^{\mathrm{b}}}$} \\
\cline { 2 - 5 } Imago & 700 & $100,0 \pm 0,0 \mathrm{a}$ & $100,0 \pm 0,0 \mathrm{a}$ & $100,0 \pm 0,0 \mathrm{a}$ \\
& 600 & $100,0 \pm 0,0 \mathrm{a}$ & $100,0 \pm 0,0 \mathrm{a}$ & $100,0 \pm 0,0 \mathrm{a}$ \\
& 500 & $92,2 \pm 1,9 \mathrm{abc}$ & $97,8 \pm 1,9 \mathrm{ab}$ & $100,0 \pm 0,0 \mathrm{a}$ \\
& 400 & $78,9 \pm 1,9 \mathrm{de}$ & $95,6 \pm 5,1 \mathrm{ab}$ & $100,0 \pm 0,0 \mathrm{a}$ \\
& 300 & $51,1 \pm 5,1 \mathrm{f}$ & $82,2 \pm 1,9 \mathrm{cde}$ & $100,0 \pm 0,0 \mathrm{a}$ \\
Nimfa & $0,0 \pm 0,0 \mathrm{~g}$ & $0,0 \pm 0,0 \mathrm{~g}$ & $0,0 \pm 0,0 \mathrm{~g}$ \\
instar III & 700 & $100,0 \pm 0,0 \mathrm{a}$ & $100,0 \pm 0,0 \mathrm{a}$ & $100,0 \pm 0,0 \mathrm{a}$ \\
& 600 & $97,8 \pm 1,9 \mathrm{ab}$ & $97,8 \pm 0,0 \mathrm{ab}$ & $100,0 \pm 0,0 \mathrm{a}$ \\
& 500 & $88,9 \pm 8,4 \mathrm{bcd}$ & $90,0 \pm 0,0 \mathrm{abc}$ & $100,0 \pm 0,0 \mathrm{a}$ \\
& 400 & $82,2 \pm 7,7 \mathrm{cde}$ & $83,3 \pm 0,0 \mathrm{cde}$ & $100,0 \pm 0,0 \mathrm{a}$ \\
& 300 & $73,3 \pm 3,3 \mathrm{e}$ & $76,7 \pm 0,0 \mathrm{e}$ & $97,8 \pm 0,0 \mathrm{ab}$ \\
& 0 (Kontrol) & $0,0 \pm 0,0 \mathrm{~g}$ & $0,0 \pm 0,0 \mathrm{~g}$ & $0,0 \pm 0,0 \mathrm{~g}$ \\
\hline
\end{tabular}

a: Standar deviasi; ${ }^{\text {b}}$ : Rata-rata persentase mortalitas yang diikuti oleh huruf yang sama menunjukan tidak berbeda nyata berdasarkan uji tukey taraf $5 \%$.

Tabel 3. Penduga parameter toksisitas fosfin formulasi cair terhadap mortalitas imago dan nimfa instar III Macrosiphoniella sanborni pada waktu papar 12 dan 15 jam

\begin{tabular}{cccccc}
\hline $\begin{array}{c}\text { Serangga } \\
\text { uji }\end{array}$ & $\begin{array}{c}\text { Waktu } \\
\text { papar/jam }\end{array}$ & $a \pm \mathrm{GB}$ & $b \pm \mathrm{GB}$ & $\begin{array}{c}\mathrm{LC}_{50} \\
(\mathrm{SK} 95 \%)(\mathrm{ppm})\end{array}$ & $\begin{array}{c}\mathrm{LC}_{95} \\
(\mathrm{SK} 95 \%)(\mathrm{ppm})\end{array}$ \\
\hline Imago & 12 & $-18,2 \pm 2,2$ & $7,3 \pm 0,8$ & 303,1 & $(277,6-323,2)$ \\
& 15 & $-13,7 \pm 3,1$ & $5,9 \pm 1,2$ & 209,8 & $(472,7-562,5)$ \\
& & & & $(144,2-248,6)$ & $(363,7-454,3)$ \\
Nimfa & 12 & $-10,2 \pm 1,8$ & $4,3 \pm 0,7$ & 228,9 & 549,3 \\
instar III & 15 & $-9,5 \pm 1,9$ & $4,1 \pm 0,7$ & $(171,7-268,3)$ & $(493,5-654,2)$ \\
& & & & $(149,4-56,5)$ & $(482,5-649,8)$ \\
\hline
\end{tabular}

$a$ : intersep garis regresi probit; $b$ : kemiringan garis regresi probit; GB: galat baku; SK: selang kepercayaan. 

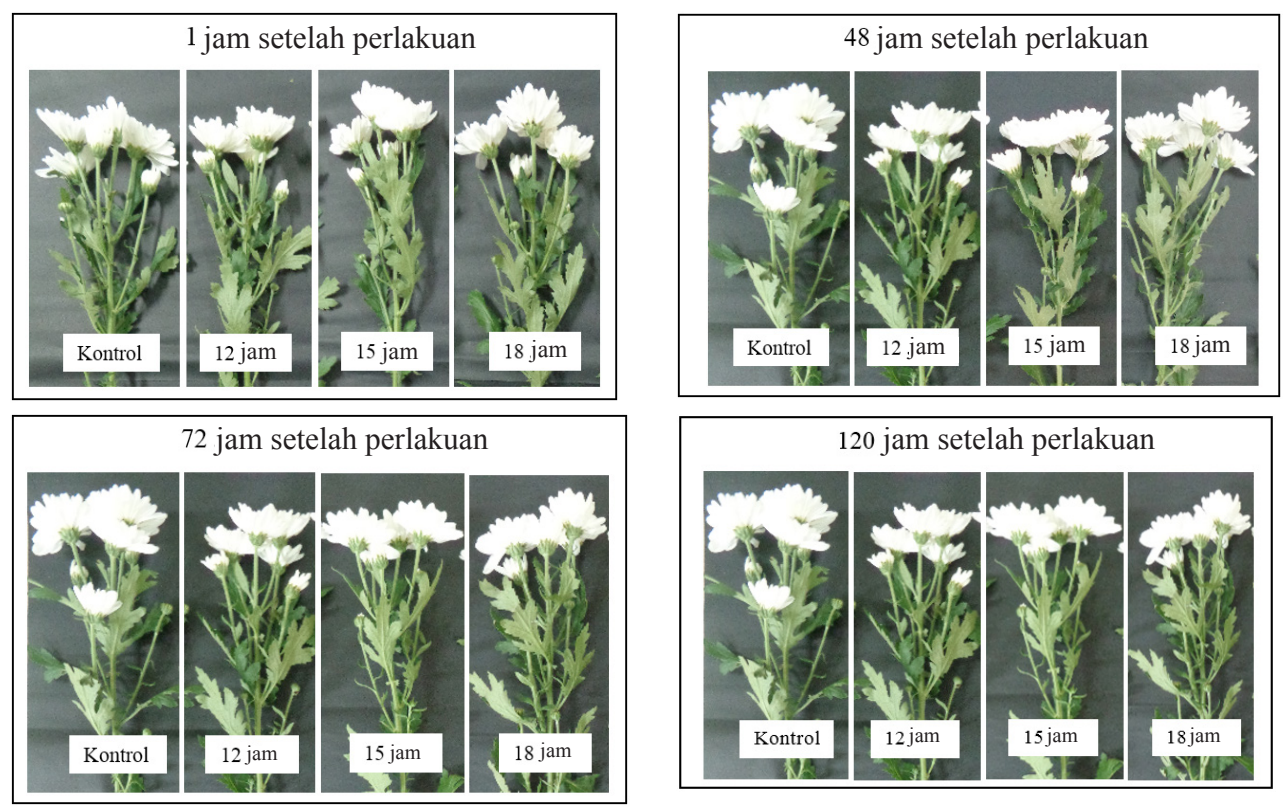

Gambar 1. Bunga potong krisan varietas Zembla white pada beberapa waktu papar dengan konsentrasi 700 ppm.
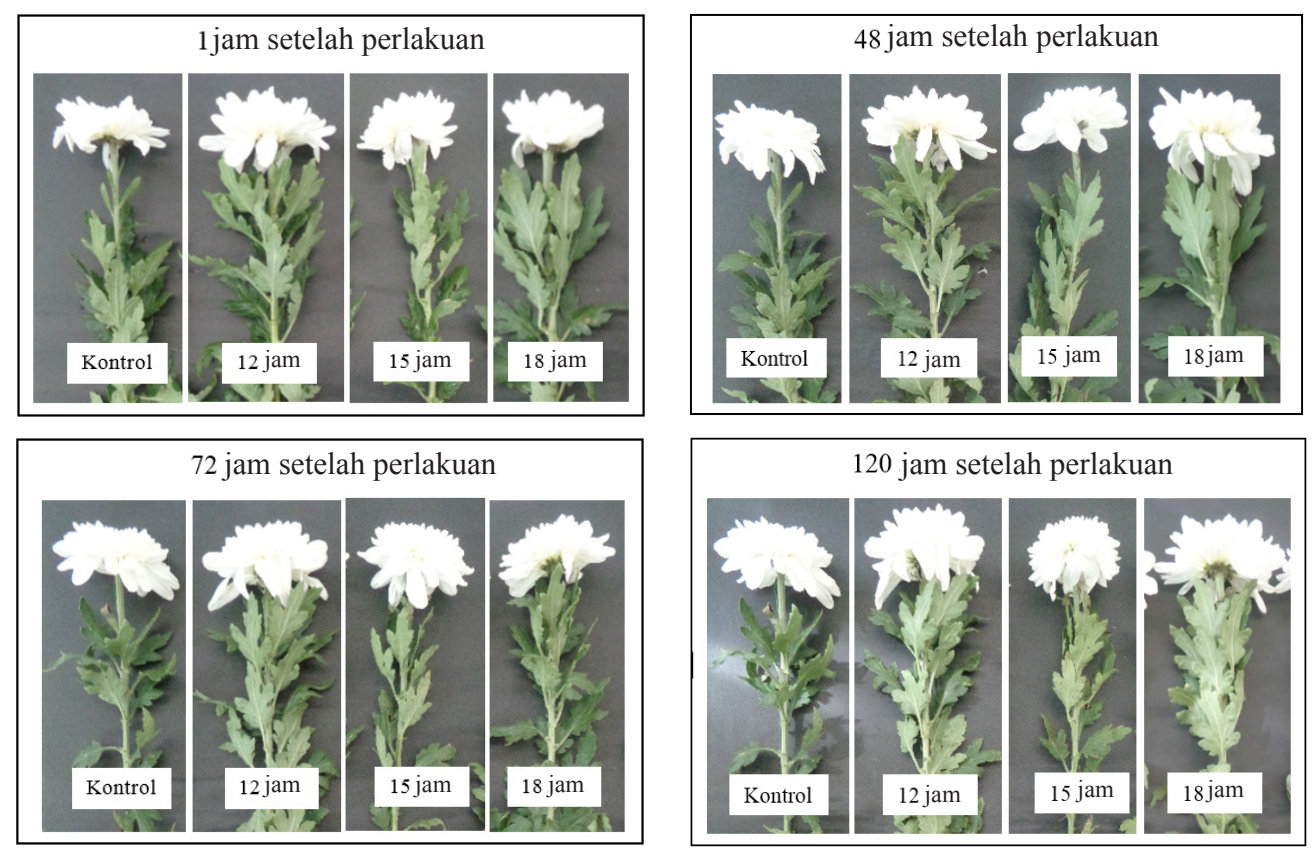

Gambar 2. Bunga potong krisan varietas Fiji white pada beberapa waktu papar dengan konsentrasi 700 ppm.

memberikan respons mortalitas beragam terhadap aplikasi fosfin formulasi cair. Pada imago Thrips parvispinus (Karny) pada bunga potong krisan fosfin formulasi cair efektif dilakukan pada konsentrasi $200 \mathrm{ppm}$ dengan waktu papar 1 jam (Setyawan 2014). Menurut Karunaratne et al. (1997), imago kutudaun dan larva Lepidoptera lebih tahan terhadap fosfin dibandingkan dengan imago thrips yang diuji pada suhu $24{ }^{\circ} \mathrm{C}$. Persentase mortalitas spesies A. gossypii lebih tinggi dibandingkan dengan $M$. sanborni. Hal ini menunjukkan bahwa fumigan fosfin formulasi cair ini memberikan respons yang berbeda untuk kedua spesies kutudaun ini. Menurut Bond (1984), penyerapan fumigan fosfin dapat bervariasi antar spesies dan fase yang berbeda.

Hasil uji lanjut aplikasi fosfin formulasi cair menunjukkan bahwa fase instar III lebih tahan dibandingkan dengan fase imago untuk kedua spesies kutudaun dan $M$. sanborni lebih tahan dibandingkan dengan A. gossypii. Hal ini sejalan dengan penelitian Park et al. (2010) bahwa fase nimfa kutudaun lebih tahan terhadap fosfin dibandingkan dengan fase imago kutudaun, thrips, 
dan tungau. Menurut Pimentel et al. (2008), populasi dengan laju respirasi (tingkat respirasi/ produksi $\mathrm{CO}_{2}$ ) yang lebih rendah menunjukkan tingkat mortalitas yang lebih rendah karena rendahnya tingkat respirasi mengakibatkan penyerapan fumigan berkurang.

Hasil analisis probit terhadap mortalitas $M$. sanborni menunjukkan bahwa toksisitas fosfin formulasi cair bergantung pada waktu papar dan konsentrasi. Dengan meningkatnya waktu pemaparan, nilai $\mathrm{LC}_{50}$ dan $\mathrm{LC}_{95}$ semakin rendah dibandingkan dengan waktu papar yang lebih singkat. Nilai $\mathrm{LC}_{50}$ pada fase imago pada waktu papar 12 dan 15 jam berturut-turut 303,1 dan 209,8 ppm, serta fase nimfa instar III berturutturut 228,9 dan 213,3 ppm. Terlihat bahwa dengan waktu papar yang lebih singkat maka persentase mortalitas sebesar 50\% membutuhkan konsentrasi yang lebih tinggi dibandingkan waktu papar yang lebih lama. Kefektifan fosfin dalam mematikan serangga bergantung pada waktu pemaparan dibandingkan dengan konsentrasi yang digunakan (Kutz 2013). Menurut Hole et al. (1976), penggunaan konsentrasi rendah dan waktu pemaparan yang lebih lama pada fumigasi menggunakan fosfin akan lebih efektif dibandingkan dengan konsentrasi tinggi dengan waktu pemaparan yang lebih singkat. Penentuan konsentrasi fosfin formulasi cair bergantung pada jenis komoditas, waktu pemaparan, jenis organisme pengganggu tumbuhan dan fase perkembangannya (Barantan 2013). Bond (1984) menyatakan bahwa selain konsentrasi dan waktu papar, faktor lain yang berpengaruh terhadap toksisitas fosfin adalah suhu. Peningkatan suhu dapat meningkatkan mortalitas karena dengan meningkatnya suhu maka laju respirasi akan semakin tinggi dan hal ini akan berkorelasi dengan banyaknya fumigan yang diserap.

Uji validasi aplikasi konsentrasi 700 ppm dengan waktu papar 12, 15, dan 18 jam menunjukkan bahwa persentase mortalitas $100 \%$ untuk kedua jenis serangga dan kedua fase serangga uji dapat tercapai, dan tidak berdampak pada kualitas bunga potong krisan varietas Zembla white dan varietas Fiji white. Persentase rata-rata kerusakan yang diamati terhadap kualitas layu dan bercak pada bunga hingga 120 JSP, tidak menunjukkan penurunan kualitas bunga potong, seperti layu dan timbulnya bercak, bila dibandingkan dengan kontrol. Tidak adanya penurunan kualitas bunga potong krisan dengan aplikasi fosfin formulasi cair sejalan dengan penelitian yang dilakukan oleh Zhang et al. (2012) terhadap Dendranthema morifolium (white chrysanthemum) yang difumigasi dengan menggunakan 3 taraf dosis 0,76, 1,52, 3,04 mg/l dengan waktu papar 2, 5, 8, dan 11 hari pada suhu $2{ }^{\circ} \mathrm{C}$, menunjukkan hasil bahwa pada semua dosis fosfin yang diuji tidak menimbulkan perubahan pada penampilan bunga. Penelitian perlakuan fosfin formulasi cair pada konsentrasi 100, 500, $4.000 \mu \mathrm{1} / 1$ terhadap bunga Protea sp. (king protea), tulip, dan Anigozanthos spp. (kangaroo paw) selama 2 dan 4 jam tidak menunjukkan hasil yang berbeda dibandingkan dengan bunga yang tidak diberikan perlakuan (kontrol) (Karunaratne et al. 1997).

Fosfin formulasi cair yang digunakan merupakan campuran $2 \%$ fosfin dan $98 \% \mathrm{CO}_{2}$. $\mathrm{CO}_{2}$ dalam campuran fumigan ini selain berfungsi sebagai gas pembawa yang baik untuk fosfin, juga berfungsi untuk menjaga agar fosfin formulasi cair tidak mudah terbakar. Menurut Barantan (2013), $\mathrm{CO}_{2}$ yang digunakan bersama dengan fosfin memiliki kecenderungan meningkatkan pernapasan serangga dan spirakel akan terbuka ketika bernapas sehingga akan mempercepat serangga mengambil konsentrasi mematikan dari fosfin formulasi cair. Penggunaan fosfin formulasi cair lebih efesien untuk mencapai hasil yang diinginkan dan waktu fumigasi dipersingkat karena reaksi sinergis tersebut. Menurut EPPO (2012), pengaruh fosfin dengan karbon dioksida menunjukkan bahwa penggunaan karbon dioksida memungkinkan pengurangan konsentrasi fosfin dan mengurangi efek fitotoksisitas pada tanaman. Selain itu, konsentrasi $\mathrm{CO}_{2}$ yang tinggi pada fosfin formulasi cair dapat menghambat proses biokimia, yaitu terhambatnya sintesa etilen sehingga dapat berfungsi sebagai penghambat laju pematangan buah (Barantan 2013). Menurut Setyadjit et al. (2012), $\mathrm{CO}_{2}$ berfungsi dalam mencegah pengaruh buruk etilen serta menghambat senesens dengan memblokir reseptor etilen yang ada pada tanaman sehingga etilen tidak dapat menempati reseptor tersebut namun tidak secara permanen. 


\section{KESIMPULAN}

Aplikasi fosfin formulasi cair terhadap $A$. gossypii dan $M$. sanborni pada bunga potong krisan efektif dilakukan pada konsentrasi berturutturut $500 \mathrm{ppm}$ dan $700 \mathrm{ppm}$ dengan waktu papar 12 jam. Pada aplikasi fosfin formulasi cair dengan kedua konsentrasi tersebut dan waktu papar hingga 18 jam tidak berdampak buruk terhadap kualitas bunga potong krisan.

\section{UCAPAN TERIMA KASIH}

Penulis mengucapkan terima kasih kepada manajemen Badan Karantina Pertanian yang telah memberikan dukungan dalam studi pascasarjana dan kepada Kepala beserta Staf Balai Uji Terap Teknik dan Metode Karatina Pertanian atas bantuan sarana untuk pelaksanaan penelitian ini.

\section{DAFTAR PUSTAKA}

[Barantan] Badan Karantina Pertanian. 2013. Keputusan Kepala Badan Karantina Pertanian Nomor 1645 Tahun 2003 tentang Standar Teknis Fosfin Formulasi Cair. Jakarta: Kementerian Pertanian.

[BPS] Badan Pusat Statistik. 2014. Data Ekspor dan Impor Chrysanthemum. Tersedia pada: http:// www.bps.go.id/ [diakses pada 28 Juli 2014].

[CABI] CAB International. 2014. Datasheets Aphis gossypii. Tersedia pada: http://www.cabi.org/isc/ datasheet/6204 [diakses pada 5 Juli 2014].

[EPPO] European and Mediterranean Plant Protection Organization. 2012. Phosphine fumigation of grapevine to control Viteus vitifoliae. Bulletin OEPP 42:496-497. doi: http://dx.doi.org/10.1111/epp.2596.

[IPPC] Secretariat of the International Plant Protection Convention. 2011. International Standards for Phytosanitary Measures (ISPM): 34, Design and Operation of Post-Entry Quarantine Stations for Plants. Rome: FAO.

Blackman RL, Eastrop VF. 2000. Aphids on the World's Crops: An Identification and Information guide. London: John Wiley \& Sons Ltd.

Blackman RL, Eastrop VF. 2006. Aphids on the World's Herbaceous Plants and Shrubs. Volume 1 - Host Lists and Keys; Volume 2 - The aphids. London: Jhon Wiley \& Son Ltd.
Bond EJ. 1984. Manual of Fumigation for Insect Control. Rome: FAO.

Dixon AFG. 1998. Aphid Ecology. $2^{\text {nd }}$ ed. New York: Chapman \& Hall.

Hole BD, Bell CH, Mills KA, Goodship G. 1976. The toxicity of phosphine to all developmental stages of thirteen species of stored product beetles. Journal Stored Product Research 12: 235-244. doi: http://dx.doi.org/10.1016/0022474X(76)90039-4.

Karunaratne C, Moore GA, Jones, RB, Ryan RF. 1997. Vase life of some cut flowers following fumigation with phosphine. HortScience 32: 900-902.

Kutz M. 2013. Handbook of Farm Dairy and Food Machinery Engineering. $2^{\text {nd }}$ ed. New York: Elsevier Inc.

Park MG, Sung BK, Tumambing J. 2010. Effect of $\mathrm{PH}_{3}$ and $\mathrm{CO}_{2}$ mixture as a quarantine fumigant in cut flowers. Conference Proceedings. Annual International Research Conference on Methyl Bromide Alternatives and Emissions Reduction; (Florida, 2010 Nov 2-5). Florida: EPA \& USDA.

Pimentel MAG, Faroni LRD, Batista MD, da Silva FH. 2008. Resistance of stored-product insect to phosphine. Pesq. agropec. bras., Brasília. 43: 1671-1676.

Rostami M, Zamani AA, Goldsteh S, Shoushtari RV, Kheradmand K. 2012. Influence of nitrogen fertilization on biology of Aphis gossypii (Hemiptera: Aphididae) reared on Chrysanthemum indicum (Asteraceae). Journal of Plant Protection Research 52:118-121. doi: http://dx.doi.org/10.2478/v10045-012-0019-2.

Setyadjit, Sukasih E, Permana AW. 2012. Aplikasi 1-MCP dapat memperpanjang umur segar komoditas hortikultura. Buletin Teknologi Pascapanen Pertanian 8:27-34.

Setyawan TT. 2014. Aplikasi Fosfin Formulasi Cair untuk Pengendalian Thrips parvispinus Karny (Thysanoptera: Thripidae) pada Bunga Potong Krisan Sebagai Perlakuan Karantina. Tesis. Bogor: Institut Pertanian Bogor.

Weller GL, Graver JE van S. 1998. Cut flower disinfestation: assessment of replacement fumigants for methyl bromide. Postharvest Biology and Technology 14:325-333. doi: http:// dx.doi.org/10.1016/S0925-5214(98)00054-4.

Zhang F, Wang Y, Liu T, Li L, Li T. 2012. Effects of low temperature phosphine fumigation on post harvest quality of white chrysanthemum 'Dabaiju'. Scientia Horticulturae 142:90-97. 